Gut , 1980, 21, 202-207

\title{
A search for persistent virus infection in Crohn's disease
}

\author{
R J PHillpotts, J HERMON-TAYLOR, N M TEICH,* AND B N BROOKE \\ From the Department of Surgery, St. George's Hospital Medical School, London
}

SUMmaRY Cell cultures derived from Crohn's disease and control tissues were subjected to a series of tests designed to detect persistent, non-cytocidal virus infection. No evidence for any such infection was found, and it is concluded that persistent viral infection of gut tissues is unlikely to play a significant role in the pathogenesis of Crohn's disease.

Animal experiments have shown that a granulomatous response may be produced in mouse footpads and rabbit ilea after injection of homogenised gut and mesenteric lymph node tissue from Crohn's disease patients. Granulomatous responses have also been produced in mice after intravenous and intraperitoneal inoculation, and in rabbits after intravenous inoculation of such homogenates. Serial passage has been achieved in both mice and rabbits suggesting that a viable transmissible agent is responsible. ${ }^{1-5}$ The Crohn's disease agent will withstand freezing and storage at $-70^{\circ} \mathrm{C}$, is destroyed by autoclaving and $2.5 \mathrm{Mr}$ irradiation, but will pass through a $220 \mathrm{~nm}$ membrane filter. ${ }^{1-4}$ These limited data on physical characterisation suggest that the putative transmissible agent from Crohn's disease could be a virus, or cell wall deficient organism such as a bacterial L-form or mycoplasma. The electron microscopic observations of Dobbins and Siemers $^{6}$ and Riemann ${ }^{7}$ similarly suggest viral involvement. Detailed studies by Phillpotts et $a^{8}$ have, however, failed to identify viruses in homogenates of Crohn's disease tissue, suggesting that if a virus is primarily involved it is not a conventional infection.

A possible mechanism for the pathogenesis of Crohn's disease is that lesions are initiated by a chronic virus infection, and exacerbated by opportunist pathogens present in the normal flora of the alimentary tract. If such a pathogenic mechanism were operative, it would be expected that a persistent non-cytocidal virus infection could be detected in cells cultured from diseased gut and mesenteric lymph node tissue of Crohn's disease patients. To this end, cell cultures were established from full

* Present address: Imperial Cancer Research Fund, Lincoln's Inn Fields, London WC2A 3PX, Fngland.

Received for publication 2 October 1979 thickness samples of bowel tissue and whole mesenteric lymph nodes from Crohn's disease and control patients, and subjected to a series of experiments designed to detect such an infection.

A search was made for ultrastructural evidence of viral infection by thin-section electron microscopy, and sera from Crohn's disease patients were used to try to detect specific antigens in the cells by immunofluorescence. Changes in the mobility of cell membrane lectin receptor sites occur as a consequence of some viral infections ${ }^{9}$; therefore the binding of fluorescein labelled lectins to each cell strain was studied. Interferon may be present in the growth medium of cell cultures persistently infected with virus. ${ }^{10}$ Crohn's disease and control cells were tested for interferon production, both spontaneous and after induction with polyinosinic-polycytidilic acid (poly I; poly C), and by challenge with Semliki Forest virus (SFV). Each cell strain was tested for persistent infection with retroviruses (ubiquitous, non-cytocidal RNA viruses which replicate by means of a DNA proviral intermediate, and are known to cause alterations in cell membrane glycoproteins), by assay of the growth medium from co-cultures of human and animal cells for reverse transcriptase, both before and after treatment with iododeoxyuridine (IUDR).

\section{Methods}

All cell culture reagents were obtained from Flow Laboratories of Irvine, Scotland.

DERIVATION OF CELL STRAINS

Mesenteric lymph nodes, and one gallbladder specimen were removed at operation and placed into sterile bottles containing $10 \mathrm{ml} 199$ medium $+20 \mathrm{mM}$ HEPES buffer, $2 \%$ inactivated foetal calf serum, 
$2 \mathrm{mM}$ L-glutamine, $1.68 \mathrm{~g} / \mathrm{NaHCO}_{3}$, penicillin/ streptomycin (p/s) 100 units per ml, gentamycin $100 \mu \mathrm{g} / \mathrm{ml}$, and fungizone $2.5 \mu \mathrm{g} / \mathrm{ml}(199 \mathrm{MM})$. Gut tissue was collected in a sterile bowl, and suitable $5 \mathrm{~cm}^{2}$ full thickness samples of macroscopically affected bowel wall were removed, trimmed of fat, scraped free of luminal contents, and placed in 199 medium as above. Specimens were washed $8 \times$ in Earle's balanced salt solution (EBSS) + antibiotics; each was sliced into $1 \mathrm{~mm}^{3}$ fragments, suspended in 20 vol EBSS $+0.5 \%$ trypsin, specific activity $1: 300$ (Wellcome Reagents, Beckenham, England) and incubated in a $37^{\circ} \mathrm{C}$ water bath, with intermittent hand shaking for 15 minutes. After replacement of the trypsin solution, incubation was continued for an additional 45 minutes in a $37^{\circ} \mathrm{C}$ incubator, with vigorous intermittent hand shaking. Remaining tissue fragments were removed using sterile gauze, the disaggregated cells were collected by centrifugation at $100 \mathrm{~g}$ for five minutes, and washed three times in a growth medium consisting of Eagle's basal medium (BME) $+20 \%$ foetal calf serum, $1 \%$ nonessential amino acids solution, $2 \mathrm{mM}$ L-glutamine, $1 \mathrm{mM}$ sodium pyruvate, $0.35 \mathrm{~g} / 1 \mathrm{NaHCO}_{3}$, and $\mathrm{p} / \mathrm{s}$ 100 units $/ \mathrm{ml}$. Cells were suspended in growth medium, and $5 \times 10^{5}$ viable cells transferred as $1 \mathrm{ml}$ samples into $13 \times 100 \mathrm{~mm}$ glass cell culture tubes, which were incubated tightly capped at $37^{\circ} \mathrm{C}$. Subculture was made into $25 \mathrm{~cm}^{2}$ flasks, using trypsin to disperse the cells, each $25 \mathrm{~cm}^{2}$ flask being subcultured $1: 2$ when confluent, usually at regular seven day intervals. After the first subculture, the growth medium was changed to Eagle's minimal essential medium $+20 \mathrm{mM}$ HEPES buffer, $10 \%$ foetal calf serum, other supplements as before (HMEM). Cells were used between passages 4-11, and were tested for mycoplasma contamination by staining with Hoechst compound 33258 (Fabwerke Hoechst, Germany).

THIN-SECTION ELECTRON MICROSCOPY Confluent monolayers in $25 \mathrm{~cm}^{2}$ flasks were resuspended in EBSS by trypsinisation, centrifuged for five minutes at $100 \mathrm{~g}$, and the pellets fixed in fresh $2.5 \%$ glutaraldehyde in $0.1 \mathrm{M}$ phosphate buffer $\mathrm{pH}(7 \cdot 2-7 \cdot 3)$ overnight at $4^{\circ} \mathrm{C}$, then post-fixed in $1 \%$ aqueous $\mathrm{OsO}_{4}$. After dehydration with ascending grades of alcohol followed by propylene oxide, fragments were embedded in Araldite. Silvergold thin sections $(60-90 \mathrm{~nm})$ were cut, and stained with uranyl acetate and lead citrate before examination under a Philips 301 electron microscope.

INDIRECT IMMUNOFLUORESCENCE

Cells were grown directly on slides, and fixed in acetone at $-25^{\circ} \mathrm{C}$ before staining by the indirect technique with sera from Crohn's disease patients. Cytomegalovirus (CMV) infected cells, prepared in the same manner, and a serum known to contain antibody to CMV were used as controls.

\section{FLUORESCENT LECTIN BINDING}

Fluorescein labelled lectins were purchased from Miles Research Laboratories, Slough, England and Pharmacia, Great Britain Limited. The cells were grown on coverslips in petri dishes, and Hams F12 medium $+2 \mathrm{mM}$ L-glutamine, 100 units $/ \mathrm{ml} \mathrm{p} / \mathrm{s}$ and without serum substituted for HMEM during the final 24 hour incubation. Each coverslip was washed in Dulbecco's complete phosphate buffered saline solution (PBS) before staining for 30 minutes at $37^{\circ} \mathrm{C}$ with $25 \mu \mathrm{g} / \mathrm{ml}$ fluorescein labelled lectin. Residual unbound lectin was removed by washing in PBS, the coverslips wet-mounted and examined with the ultra-violet microscope. The specificity of lectin binding was controlled by preparing other cells in the presence of $0.1 \mathrm{M}$ of the appropriate sugar. Cells were also examined after neuraminidase treatment.

INTER FERON ASSA Y

$\mathrm{MRC}_{5}$ human embryo lung cells ${ }^{11}$ were grown in HMEM, and maintained on 199 MM. Human fibroblast interferon was assayed using these cells challenged with SFV. $0.1 \mathrm{ml}$ volumes of serial 0.5 $\log _{10}$ or $\log _{2}$ dilution of interferon preparation were added to each well of microtitre plates containing $\mathrm{MRC}_{5}$ cells, and incubation continued for a further 24 hours. Residual interferon and non-specific inhibitors were removed by washing the cell sheets five times in EBSS, before challenge with $10050 \%$ cell culture infective doses $\left(\mathrm{CCD}_{50}\right)$ of SFV. After 48 hours' incubation at $37^{\circ} \mathrm{C}$, cell destruction in each well was estimated on a scale of 0-4 and the dilution of interferon protecting $50 \%$ of cells calculated using the method of Kärber. ${ }^{12}$ On each occasion the virus was titrated and an internal standard preparation of human fibroblast interferon was included to demonstrate reproducibility of the assay.

Assessment of cell strains for spontaneous interferon production: HMEM growth medium from subcultures of each of the Crohn's disease and control cell strains was stored at $-70^{\circ} \mathrm{C}$, until approximately $150 \mathrm{ml}$ were obtained. Aliquots from each cell strain were pooled, and a sample withdrawn for interferon testing. Phosphate buffer ( $\mathrm{pH} \mathrm{6.5)} \mathrm{was}$ added to the remainder to a final concentration of $0.2 \mathrm{M}$, followed by acidification to $\mathrm{pH} 2.0$ with $1.5 \mathrm{M}$ perchloric acid. The suspension was clarified by centrifugation at $70000 \mathrm{~g}$ for 30 minutes, then concentrated by dialysis overnight at $4^{\circ} \mathrm{C}$ against 40 vol of $10 \%$ polyethylene glycol (m. wt. 18-24000) 
in PBS (pH 2.0) followed by a further 24 hour dialysis against $100 \mathrm{vol} \mathrm{PBS}\left(\mathrm{pH} \mathrm{7 \cdot 2)}\right.$ at $4^{\circ} \mathrm{C}$. Concentrated preparations were stored at $-70^{\circ} \mathrm{C}$.

Interferon induction with poly $\mathrm{I}$ : poly $\mathrm{C}$ : Equal volumes of $70 \mu \mathrm{g} / \mathrm{ml}$ poly I: poly C (Miles Research Laboratories, Slough, England) and $200 \mu \mathrm{g} / \mathrm{ml}$ DEAE dextran in Eagle's minimal essential medium without serum were mixed, and placed in a $37^{\circ} \mathrm{C}$ water bath for 30 minutes. Confluent $25 \mathrm{~cm}^{2}$ monolayers from each cell line were washed five times in EBSS, and exposed to $2 \mathrm{ml}$ poly $\mathrm{I}$ : poly $\mathrm{C}$, DEAE dextran solution for one hour at $37^{\circ} \mathrm{C}$. After washing an additional five times in EBSS, $5 \mathrm{ml}$ $199 \mathrm{MM}$ was added, and the cells incubated for 24 hours. Medium was harvested, pooled, and treated with $50 \mu \mathrm{g} / \mathrm{ml}$ pancreatic ribonuclease $A$ and 300 units $/ \mathrm{ml} \mathrm{T}_{1}$ ribonuclease (Sigma Chemicals, Poole, England) for two hours at $37^{\circ} \mathrm{C}$. The number of cells in each flask was determined, and induced interferon was expressed as $50 \%$ cell culture protective doses $\left(\mathrm{CCPD}_{50}\right)$ per $10^{5}$ cells.

\section{CHALLENGE OF CELL STRAINS WITH SFV}

Confluent cell monolayers from each Crohn's derived and control cell culture were prepared in microtitre plates, fed with $199 \mathrm{MM}$, and incubated for an additional 24 hours before being used for the titration of SFV. Cytopathic effect (CPE) was estimated on a scale of $0-4$ on the fourth day, and the dilution of virus infecting $50 \%$ of cell cultures was calculated using the method of Kärber. ${ }^{12}$

\section{CO-CULTIVATION AND REVERSE}

TRANSCRIPTASE ASSAY

Cell strains from six Crohn's disease patients (four ileum, two colon) and seven controls (three ileum, three colon, one lymph node) were co-cultured with and without $20 \mu \mathrm{g} / \mathrm{ml}$ of IUDR in the growth medium with mouse SC-1 ${ }^{13}$ and mink Mv1Lu cells. ${ }^{14}$ In all experiments mouse AKR 2B cells, ${ }^{15}$ which are highly inducible for ecotropic and xenotropic retrovirus, were treated along with the Crohn's disease and control cell cultures to serve as positive controls for IUDR induction. In addition, two Crohn's disease cell strains, and two controls (all from ileum) were co-cultivated with Vero monkey kidney $^{16}$ and Tb-1-Lu bat cells (American Type Culture Collection CCL88).

Co-cultures were passaged at weekly intervals for five weeks, the cell culture fluids harvested, and assayed for reverse transcriptase. Reverse transcriptase activity was considered to be present if the ratio of oligo dT-poly rA to oligo dT-poly dA directed tritiated thymidine pyrophosphate uptake was greater than $2 .{ }^{17}$

\section{Results}

The cell strains were derived from patients with active Crohn's disease and controls as shown in Table 1. All were fibroplastic in appearance, and throughout 11 subcultures none of them showed any sign of spontaneous degeneration, or any cytopathic effect (CPE) which could be attributed to virus.

Seven Crohn's disease cell strains from five patients (two lymph node, one colon, one gallbladder, and three ileum) and seven controls from seven patients (four colon, two ileum, and one lymph node) were examined by thin section electron microscopy. None of the cells showed any signs of virus infection and no virus particles were seen.

Cell strains from six Crohn's disease patients (four ileal and two colon) and seven controls (four ileal, two colon, and two lymph node) were tested for

Table 1 Cell lines derived from Crohn's disease and control tissues

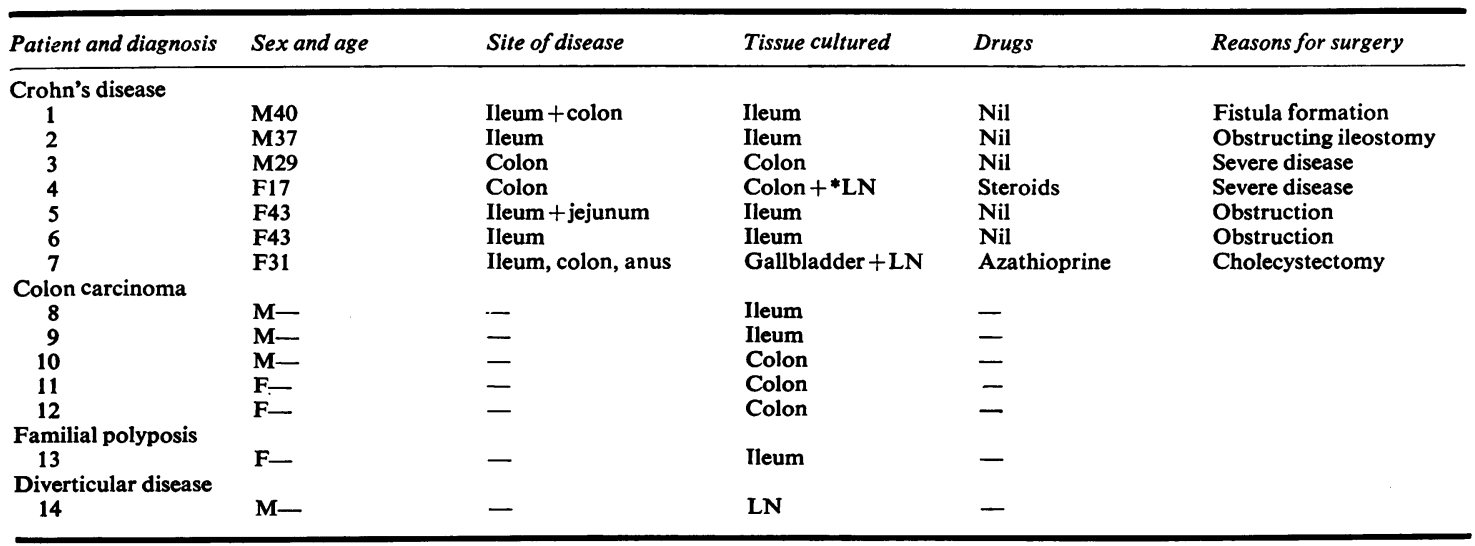

*LN: Lymph node. 
specific immunofluorescence. Of the sera used from the 18 Crohn's disease patients five were from patients in remission and $\mathbf{1 3}$ from those with active disease. None of these patients had taken steroid drugs, or undergone any major surgical procedures during the two months before donating the serum sample. No specific fluorescence was found against any of the cell strains tested.

Six Crohn's disease (four ileal, two colon) and six control cell strains (two ileal and four colon) were examined for their capacity to bind fluorescent labelled lectins. The lectins used, their sugar specificities, and the extent of the staining of the various cells are shown in Table 2. Crohn's disease and control cells showed identical lectin specificities. There was no apparent difference in the aggregation and distribution of fluorescent lectin on the cell surface of Crohn's disease and control cells.

Interferon was assayed in spent growth medium from seven Crohn's disease (three ileal, one colon, two lymph node, and one gallbladder) and seven control (two ileal, four colon, one lymph node) cell strains both before and after concentration (10- to 20-fold). No interferon-like activity was detected in any of the unconcentrated or concentrated samples. The results of interferon induction in the various cell strains using poly $\mathrm{I}$ : poly $\mathrm{C}$ are shown in Table 3. All produced some interferon, though the response was variable in both Crohn's disease and control derived cultures. When these data were analysed using the $t$ test for unpaired variates, there was no significant difference between the levels of interferon induced in Crohn's disease and control cell cultures $(t=0.522, \mathrm{P}=\gg 0.05)$.

The titre of the SFV produced in each cell strain is shown in the histogram (Figure). There was no significant difference in the mean titres of SFV in Crohn's disease and control cell strains $(t=0 \cdot 84$, $P=\gg 0.05$ ), and none of the Crohn's disease cells lacked susceptibility to SFV.

Treatment with IUDR, followed by co-cultivation and assay for reverse transcriptase, failed to demonstrate retrovirus infection of any of the gut tissue derived cell strains that were tested. Supernatant fluids from AKR 2B cells were invariably positive for reverse transcriptase activity one to two weeks after IUDR treatment.

\section{Discussion}

The tests applied to cells cultured from Crohn's disease and control patients in this study failed to detect any persistent, non-cytocidal virus infection. No virus particles were found in any of the cells by thin-section electron microscopy, but the sensitivity of this method is low, as virus particles must either be present in large numbers or be distinctive in appearance before they can be definitely identified. These problems are particularly relevant when studying persistent infections of cell cultures, as it is possible that only a small number of cells will be infected, and these may be producing incomplete and morphologically abnormal virus. Similarly, indirect immunofluorescence using sera from Crohn's

Table 2 Fluorescent lectin binding specificities

\begin{tabular}{|c|c|c|c|}
\hline \multirow[b]{2}{*}{ Lectin } & \multirow[b]{2}{*}{ Sugar specificity } & \multicolumn{2}{|l|}{ Binding to cells } \\
\hline & & Before neuraminidase treatment & After neuraminidase treatment \\
\hline $\begin{array}{l}\text { Wheatgerm-agglutinin } \\
\text { (WGA) }\end{array}$ & $\alpha$-N-acetyl D-glucosamine & $+t+$ & ND \\
\hline $\begin{array}{l}\text { Ricinus communis } \\
\text { (RCA II) }\end{array}$ & $\begin{array}{l}\alpha \text {-D-galactose } \\
\alpha \text {-N-acetyl D-galactosamine }\end{array}$ & ++ & ++ \\
\hline Soya bean & , & - & - \\
\hline Helix pomatia & $\alpha-N$-acetyl D-galactosamine & - & - \\
\hline Lotus tetragonolobus & $\alpha$-L-fucose & 一 & - \\
\hline
\end{tabular}

ND: not done.

Table 3 Results of poly I: poly C interferon induction in Crohn's disease and control cell lines

\begin{tabular}{|c|c|c|c|}
\hline Crohn's disease cell line from: & Induced interferon $C C P D_{50} / 10^{s}$ cells & Control cell lines from: & $\begin{array}{l}\text { Induced interferon } C C P D_{30} / 10^{5} \\
\text { cells }\end{array}$ \\
\hline $\begin{array}{l}\text { Ileum }\{ \\
\text { Colon }\{ \\
\text { Mean }\end{array}$ & $\begin{array}{r}1259 \\
251 \\
631 \\
1000 \\
200 \\
200 \\
589\end{array}$ & $\begin{array}{l}\text { Ileum }\{ \\
\text { Colon }\{\end{array}$ & $\begin{array}{r}1820 \\
316 \\
158 \\
1000 \\
794 \\
55 \\
692\end{array}$ \\
\hline
\end{tabular}




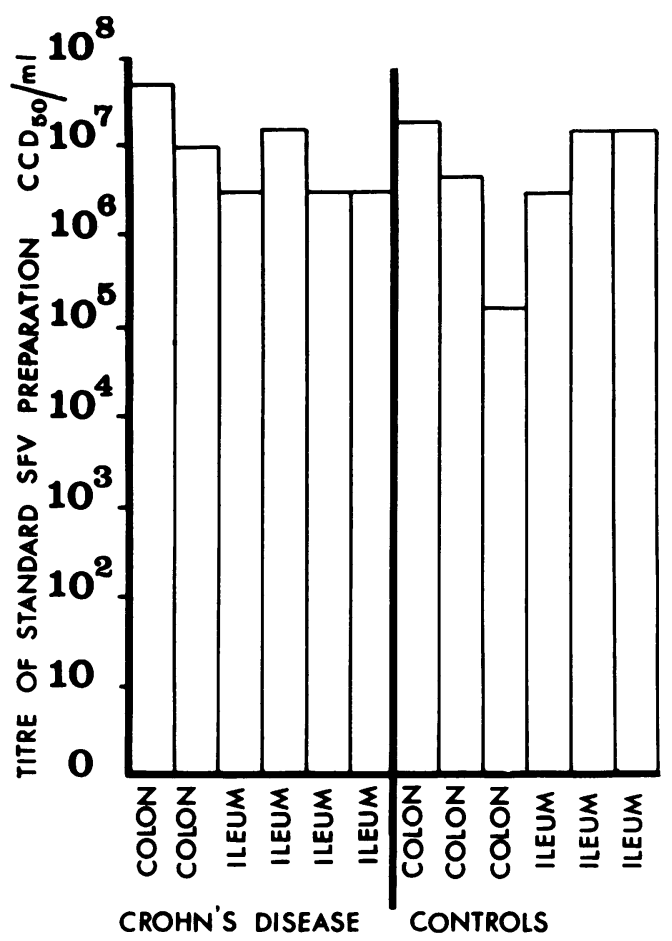

Figure Titration of SFV in Crohn's disease and control cell strains

disease patients failed to show any specific fluorescence, though this could have been due to lack of antibody in the sera or to the absence of virus from the cell cultures.

Lectins are known to bind to oligosaccharide structures including viral glycoproteins. Studies of lectin interaction with virus infected cells have concentrated on the changes in cell agglutinability which occur in cells infected with non-oncogenic as well as oncongenic viruses, and which are a consequence of an increased mobility of the lectin receptor sites. ${ }^{9}$ In the present study no redistribution of lectin receptor sites or difference in lectin specificity was identified between Crohn's disease and normal tissue derived cell strains.

Interferon has been found to be involved in the mediation of some persistent in vitro virus infections, and small amounts may be present in the cell culture fluid. The equilibrium of such cultures is upset by the addition of interferon antibody, and the cells may be refractory to further interferon induction. ${ }^{18-22}$ Although considerable variability in response to interferon induction by poly $\mathrm{I}$ : poly $\mathrm{C}$ was noted in both Crohn's and control cell strains, none appeared to be refractory to interferon induction. None of the cell cultures produced interferon spontaneously, as shown by their uniform sensitivity to SFV and the apparent absence of interferon from spent growth medium, even after concentration.

Retrovirus infection of these cells was not detected before or after IUDR treatment and co-cultivation studies. However, the assay for reverse transcriptase is suitable only for the detection of mammalian $\mathrm{C}$ - and D-type viruses, as $\mathrm{Mn}^{++}$was used as the divalent cation in the reaction mixture, ${ }^{23}{ }^{24}$ and one cannot exclude the possibility of low levels of virus production.

Trypsinisation of tissue is a standard procedure for the establishment of cell cultures ${ }^{25}$; in this study the 'batch' technique used has the disadvantage that the proportion of cells inevitably killed may have been those infected by virus. Furthermore, cells produced by the trypsin disaggregation of tissues are fragile, and easily destroyed by mechanical stress, such as centrifugation. The cell culture techniques used favoured the survival of fibroblast-like cells, and others, particularly those of epithelial origin which are difficult to grow, would not have propagated in the culture flasks. Thus a considerable selection of cells would have occurred during the establishment and subculture of the cell strains. There is no evidence to suggest that the cell populations studied must necessarily have been those infected with any virus present in Crohn's disease tissues. For this reason, although these results do not support the concept of persistent virus infection in the pathogenesis of Crohn's disease, they do not enable such a mechanism to be excluded.

The technical assistance of Janice Rowe is gratefully acknowledged. This project was supported by a grant from the Medical Research Council.

\section{References}

${ }^{1}$ Taub R N, Silizbach L E. Induction of granulomas in mice by injection of human sarcoid and ileitis homogenates. In: Iwai K, Hosoda Y, eds. Proceedings of the VI International Conference on Sarcoidosis. Tokyo: University of Tokyo Press, 1974; 20-1.

${ }^{2}$ Cave D R, Mitchell D N, Brooke B N. Experimental animal studies on the etiology and pathogenesis of Crohn's disease. Gastroenterology 1975; 69: 618-24.

${ }^{3}$ Cave D R, Mitchell D N, Brooke B N. Induction of granulomas in mice by Crohn's disease tissues. Gastroenterology 1978; 75: 632-7.

${ }^{4}$ Mitchell D N, Rees R J W, Goswami K K A. Transmissible agents from human sarcoid and Crohn's disease tissues. Lancet 1976; 2: 761-5.

${ }^{5}$ Simonowitz D, Block G E, Riddell R H, Kraft S. C, Kirsner J B. The production of an unusual tissue reaction in rabbit bowel injected with Crohn's disease homogenates. Surgery 1977; 82: 211-8.

${ }^{6}$ Dobbins W O, and Siemers P T. A viral etiology for inflammatory bowel disease? (Abstract) Gastroenterology 1972; 62 : 742. 
${ }^{7}$ Riemann J F. Further electron microscopic evidence of virus-like particles in Crohn's disease. Acta Hepatogastroenterol (Stuttg) 1977; 24: 116-8.

${ }^{8}$ Phillpotts R J, Hermon-Taylor J, Brooke B N. Virus isolation studies in Crohn's disease: a negative report. Gut (in press).

${ }^{9}$ Nicholson G L. The interactions of lectins with animal cell surfaces Int Rev Cytol 1974; 39: 89-190.

${ }^{10}$ Walker D L. The viral carrier state in animal cell cultures. Prog Med Virol 1964; 6: 111-48.

${ }^{11}$ Jacobs J P, Jones C M, Baille J P. Characteristics of a human diploid cell line designated $\mathrm{MRC}_{5}$. Nature 1970; 227 : 168-70.

${ }^{12}$ Karber G. Beitrag zur kollektiven Behandlung pharmakologischer Reihenversuche. Naunyn Schmiedebergs Arch Pharmacol. 1931 ; 162: 480-3.

${ }^{13}$ Hartley J W, Rowe W P. Clonal cell lines from a feral mouse embryo which lack host range restrictions for murine leukemia viruses. Virology 1975; 65: 128-34.

${ }^{14}$ Henderson I C, Lieber M M, Todaro G J. Mink cell line Mv1Lu (CCL64): Focus formation and the generation of "non-producer" transformed cell lines with murine and feline sarcoma viruses. Virology 1974; 60: 282-7.

${ }^{15}$ Rowe W P, Hartley J W, Lander M R, Pugh W G, Teich N M. Non-infectious AKR mouse embryo cell lines in which each cell has the capacity to be activated to produce infectious murine leukemia virus. Virology 1971; 46: 866-76.

${ }^{16}$ Yasamura Y, Kawakita Y. Research into SV40 by tissue culture. Nippon Rinsho 1963; 21 : 1201-19.
${ }^{17}$ Baltimore D, Smoler D. Primer requirement and template specificity of the DNA polymerase of RNA tumor viruses. Proc Natl Acad Sci USA 1971; 68: 1507-11.

${ }^{18}$ Inglot A D, Albin M, Chudzio T. Persistent infection of mouse cells with Sindbis virus: role of virulence of strains, auto-interfering particles and interferon. $J$ Gen Virol 1973; 20: 105-110.

${ }^{19}$ Ito $Y$, Nishiyama Y, Shimokata K, Kimura Y, Nagata I, Kinii A. Interferon production in L-cells persistently infected with hemagglutinating virus of Japan (HVJ). Virology 1976; 71: 463-70.

${ }^{20}$ Collins A R, Flanagan T D. Interferon production and response to exogenous interferon in two cell lines of mouse brain origin persistently infected with Sendai virus. Arch Virol 1977; 53: 313-21.

${ }^{21}$ Nishiyama Y. Studies of L-cells persistently infected with VSV: factors involved in the regulation of persistent infection. J Gen Virol 1977; 35: 265-79.

${ }^{22}$ Ramseur J M, Friedman R M. Prolonged infection of interferon treated cells by vesicular stomatitis virus: possible role of temperature sensitive mutants and interferon. J Gen Virol 1977; 37: 323-33.

${ }^{23}$ Scolnick E, Rands E, Aaronson S A, Todaro G J. RNA-dependent DNA polymerase activity in five RNA viruses: divalent cation requirements. Proc Natl Acad SciUSA 1970; 76: 1789-96.

${ }^{24}$ Verma I M. The reverse transcriptase. Biochim Biophys Acta $1977 ;$ 473: 1-38.

${ }^{25}$ Rappaport C. Trypsinization of monkey-kidney tissue: an automatic method for the preparation of cell suspensions. Bull WHO 1956; 14: 147-66. 